\title{
Prototype Sistem Monitoring Volume Bak Sampah Online Berbasis Arduino Nano dan Orange Pi
}

\author{
Andi Mappatoba ${ }^{1}$, Ilham Haruna ${ }^{2}$ Agussalim $^{3}$ \\ ${ }^{1,2}$ Sistem Komputer STMIK Handayani, Jl. Adhyaksa No. 1 Makassar, Indonesia \\ ${ }^{3}$ Sistem Informasi Universitas Pembangunan Nasional Veteran Jawa Timur, Jl. Rungkut Madya No. 1 Surabaya, Indonesia
}

\section{ARTICLE INFORMATION}

Received: January $26^{\text {th }}, 2020$

Revised: March $11^{\text {th }} .2020$

Available online: March $30^{\text {th }}, 2020$

\section{KEYWORDS}

monitoring, trash can, online, orange pi,

Arduino uno

\section{CORRESPONDENCE}

Phone: +6281355150658

E-mail: agussalim.si@upnjatim.ac.id

\section{A B $\mathbf{S}$ T $\mathbf{R}$ A $\mathbf{C}$ T}

This research aims to develop trash volume monitoring based on Arduino nano and orange pi. This prototype detected trash volume in the trash can, and send the information through the monitoring server via a cellular network in real-time. So that the trash management, in this case, Dinas Kebersihan, could be efficient. In which the trash can located in various places could be easily monitored through the website. The results show, optimum range for the sensor that installed in the trash can is maximal $25 \mathrm{~cm}$, in which for every trash that detected by sensor must be in range of $0 \mathrm{~cm}$ between $4.5 \mathrm{~cm}$, where the position of the sensor does not face to face so that the sensor detects more accurately in determining the volume of free space in the trash

\section{INTRODUCTION}

Pengumpulan sampah merupakan satu masalah logistik yang paling kompleks yang dihadapi kota manapun [11]. Dalam beberapa tahun terakhir kenaikan harga BBM, biaya operasional dan beban regulasi yang berkembang telah menyebabkan perusahaan pengumpulan sampah baik milik pemerintah maupun swasta perlu mengoptimalkan rute pengumpulan sampah mereka. Perbaikan kecil pada rute pengumpulan sampah berdampak besar pada penghematan biaya operasional.

Bentuk pelayanan yang diberikan pemerintah daerah ialah mobil pengangkut sampah yang digunakan untuk mengangkut sampah dari Tempat Pembuangan Sementara (TPS) ke Tempat Pembuangan Akhir (TPA). Proses pengangkutan sampah di TPS yang dilaksanakan mobil pengangkut tersebut masih membutuhkan waktu yang lama. Hal ini mengakibatkan penumpukan timbunan sampah yang melebihi kapasitas TPS.. Karena timbunan sampah yang meluap, sampah sangat berserakan hingga memasuki badan jalan dan menjadikan daerah terlihat sangat kumuh.

Saat ini, metode pengangkutan sampah dilakukan dengan cara mengambil semua sampah yang ada dengan mendatangi secara https://doi.org/10.25077/jitce.4.01.22-27.2020 langsung TPS. Tidak peduli kontainer sampah dalam keadaan penuh atau tidak.

Dari permasalahan tersebut, maka kami mengembangkan prototype manajemen monitoring volume sampah pada bak sampah secara jarak jauh. Semua fasilitas monitoring akan diakftifkan secara otomatis pada saat ada sampah yang terdeteksi, sistem ini dapat memonitor lokasi TPS yang penuh, dan secara otomatis memberikan pemberitahuan lokasi dan volume TPS tersebut. Saat ini arduiono telah banyak digunakan untuk membangun system monitoring, antara lain Monitoring Pemakaian Energi Listrik Rumah Berbasis Mikrokontroller Secara Wireless [1], Rancang Bangun Magnetic Door Lock Menggunakan Keypad Dan Solenoid Berbasis Mikrokontroler Arduino Uno [3], dan Prototype Sistem Pengunci Pintu Melalui Internet Menggunakan Arduino Uno Berbasis Android [4]. Begitupun pemanfaatan system monitoring yang menggunakan jaringan internet seperti pada penelitian [5].

Prototype monitoring bak sampah yang dikembangkan berbasis Arduino Nano dan Orange Pi dan terhubung dengan jaringan seluler. Sehingga setiap bak sampah pada TPS dapat untuk mendeteksi volume sampah yang ada dalam bak sampah dan mengirimkan data melalui jarigngan selular menuju monitoring server. Kantor pemerintah terkait dapat melihat informasi volume 
sampah melalui website secara real time sehingga pengelolaan manajemen kebersihan lebih efektif.

\section{Arduino Nano}

Arduino Nano adalah board mikrokontroler berbasis ATmega328 (datasheet). Memiliki 14 pin input dari output digital dimana 6 pin input tersebut dapat digunakan sebagai output PWM (Pulse Width Modulation) dan 6 pin input analog, $16 \mathrm{MHz}$ osilator kristal, koneksi USB, jack power, ICSP header, dan tombol reset. Untuk mendukung mikrokontroler agar dapat digunakan, cukup hanya menghubungkan Board Arduino Nano ke komputer dengan menggunakan kabel USB atau listrik dengan AC yang-ke adaptor-DC atau baterai untuk menjalankannya [2].

\section{Orange Pi}

Orange Pi PC ditenagai dengan mikroprosesor AllWinner H3 Quad-core CortexA7 H.265/HEVC 4K CPU, GPU Mali400MP2 yang bekerja pada $600 \mathrm{MHz}$ dan mendukung OpenGL ES 2.0, 1GB DDR3 yang dibagi dengan GPU, konektor Ethernet RJ45, dan sebuah slot MMC /TF card . Orange Pi, dilengkapi dengan konektor masukan CSI untuk kamera, sebuah microphone, dan $3.5 \mathrm{~mm}$ jack. Sebuah port HDMI dan 3 port USB 2.0 serta satu port USB 2.0 OTG port. 40 pin header GPIO nya kompatibel penuh dengan Raspberry Pi B + dan Raspberry Pi 2. Orange Pi PC dapat menjalankan distribusi GNU/Linux Ubuntu dan Debian hingga android [10].

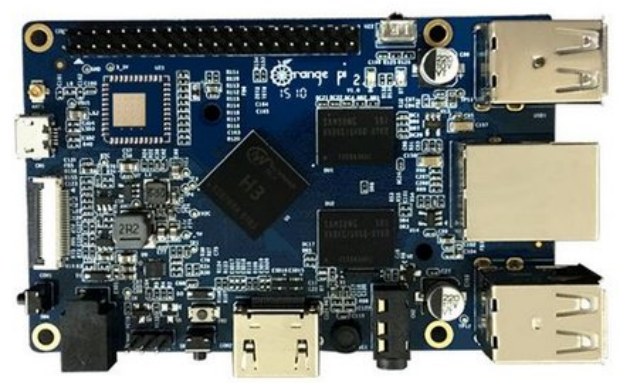

Gambar 1. Orange Pi Mini 2

\section{Sistem Sensor Inframerah}

Sistem sensor infra merah pada dasarnya menggunakan infra merah sebagai media untuk komunikasi data antara receiver dan transmitter. Sistem akan bekerja jika sinar infra merah yang dipancarkan terhalang oleh suatu benda yang mengakibatkan sinar infra merah tersebut tidak dapat terdeteksi oleh penerima. Keuntungan atau manfaat dari sistem ini dalam penerapannya antara lain sebagai pengendali jarak jauh, alarm keamanan, otomatisasi pada sistem. Pemancar pada sistem ini tediri atas sebuah LED infra merah yang dilengkapi dengan rangkaian yang mampu membangkitkan data untuk dikirimkan melalui sinar infra merah, sedangkan pada bagian penerima biasanya terdapat foto transistor, fotodioda, atau inframerah modul yang berfungsi untuk menerima sinar inframerah yang dikirimkan oleh pemancar [12].

\section{LED Infra Merah}

LED adalah suatu bahan semikonduktor yang memancarkan cahaya monokromatik yang tidak koheren ketika diberi tegangan maju. Pengembangan LED dimulai dengan alat inframerah dibuat dengan galliumarsenide. Cahaya infra merah pada dasarnya adalah radiasi elektromagnetik dari panjang gelombang yang lebih panjang dari cahaya tampak, tetapi lebih pendek dari radiasi gelombang radio, dengan kata lain inframerah merupakan warna dari cahaya tampak dengan gelombang terpanjang, yaitu sekitar $700 \mathrm{~nm}$ sampai $1 \mathrm{~mm}$ [13].

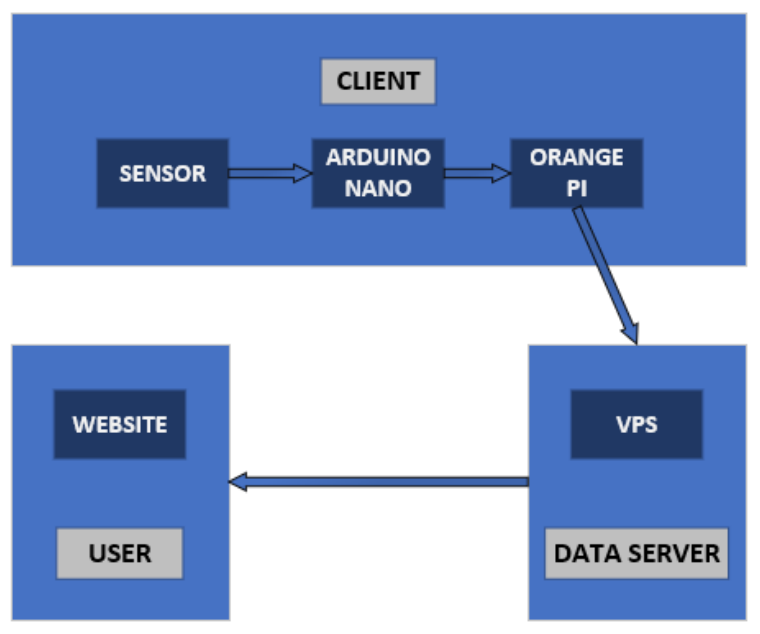

Gambar 2. Diagram Sistem

\section{METODOLOGI}

Penelitian ini merupakan penelitian ekperimental, dimana data didapatkan dari beberpa kali percobaan [6]. Untuk menyelesaikan permasalahan yang dijelaskan sebelumnya, berikut langkahlangkah pengembangan prototype system. Secara umum perancangan prototype sistem ini dibangun dari tiga bagian utama seperti terlihat pada Gambar 2, yaitu sebagai berikut :

1. Tempat Sampah (Client)

Tempat Sampah bertindak sebagai client terdiri dari Sensor IR Obstacle, Arduino Nano, Orange Pi. IR Obstacle Sensor infrared merupakan sebuah modul yang berfungsi sebagai pendeteksi halangan atau object di depannya. Dimana setiap sensor ketika dihalangi oleh sampah yang masuk pada bak sampah, sensor akan mengirim data ke Arduino Nano, kemudian ketika bak sampah telah penuh data akan dikirim ke Arduino Nano lalu data dari Arduino Nano akan dikirim ke Orange $P i$ untuk mengirim data ke server melalui jaringan wirelass.

2. Virtual Private Server (Data Server)

Server Data sendiri berfungsi sebagai pusat data acuan dan memproses data yang diterima dari sistem Tempat Sampah (Client) melalui jaringan wirelass, kemudian data yang telah diproses akan dikirim menuju Website User melalui jaringan wirelass. 
Website berfungsi sebagai monitoring lokasi tempat sampah yang telah penuh untuk diambil dari TPS menuju TPA. Sistem ini terbagi menjadi 3 komponen utama yakni; 1) komponen perangkat yang mendeteksi volume / sampah yang ada pada bak sampah; 2) perangkat server tempat semua data sensor terolah disimpan; 3 ) sistem informasi yang berjalan di perangkat operator atau pengguna.

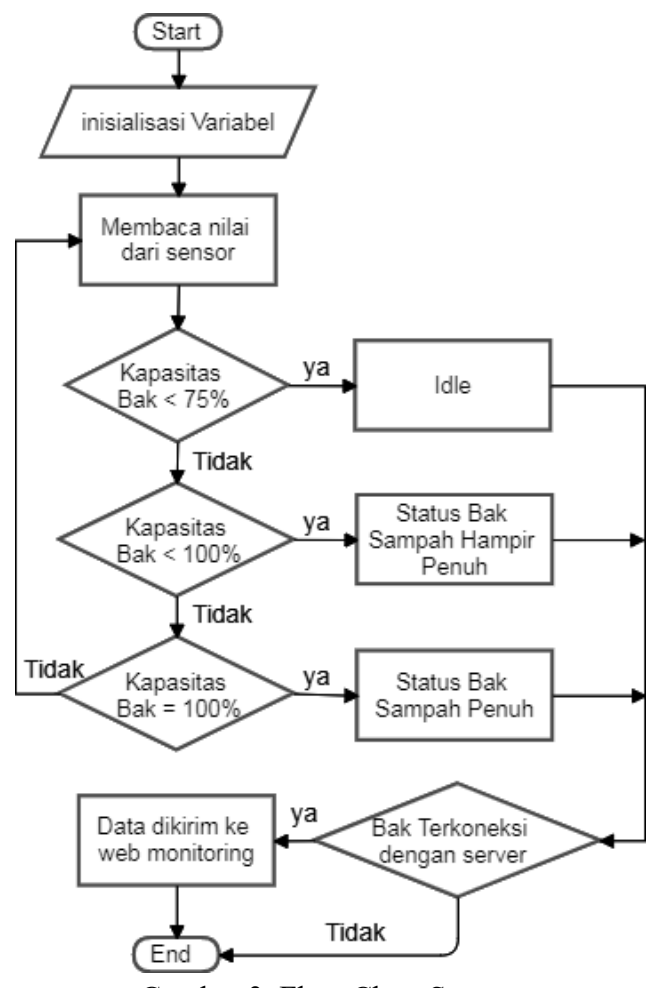

Gambar 3. Flow Chart System

\section{Flowchart System}

Gambar 3 memperlihatkan flowchart system dari prototype yang dikembangkan. Pada flowchart terdapat beberapa langkah yang dilakukan antara lain:

1. Inisialisasi nilai variabel

2. Memberi nilai volume sampah ke dalam sistem, nilai sensor infrared

3. Mengecek nilai volume sampah kurang dari $75 \%$ lalu mengeluarkan status "IDLE" melalui web dan bersamaan dengan itu sistem mengecek koneksi

4. Mengecek nilai volume sampah kurang dari $100 \%$ sistem akan mengeluarkan status pada web "Status Penampungan Hampir Penuh" dan bersamaan dengan itu sistem mengecek koneksi

5. Mengecek nilai volume sampah $=100 \%$ maka sistem akan mengeluarkan status melalui web "Penampungan Penuh, "Silahkan Ambil Pengangkutan" dan bersamaan dengan itu sistem mengecek koneksi

6. Data volume sampah diterima web interface

\section{Pengembangan Prototype}

Pada gambar 4, terlihat diagram protoype dari monitoring tempat sampah yang dikembangkan. Komponen pada input adalah berupa sensor Infrared Obstacle yang dipasanag 2 sensor pada setiap sisi tempat sampah untuk mengambil nilai dari volume sampah yang ada. Pada bagian proses memiliki komponen berupa arduino nano yang menggunakan IC ATMega328 yang berfungsi untuk memproses data dari sensor infrared obstacle.

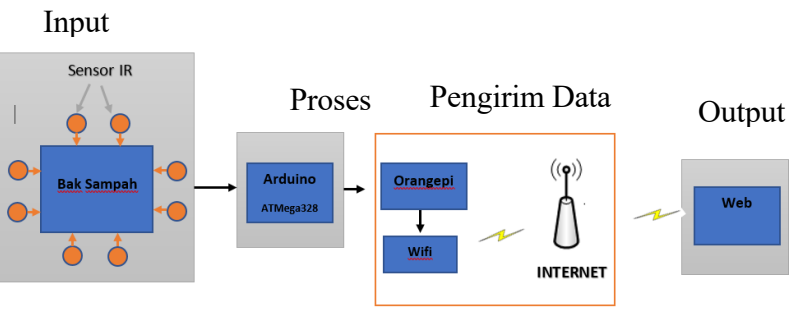

Gambar 4. Diagram Prototype

Untuk bagian pengirim data memiliki komponen berupa orange pi, usb wirelass dan wifi yang berfungsi untuk mengirim data dari arduino ke server. Pada bagian output memiliki komponen berupa interface web yang berguna untuk menampilkan presentasi volume sampah pada bak sampah.
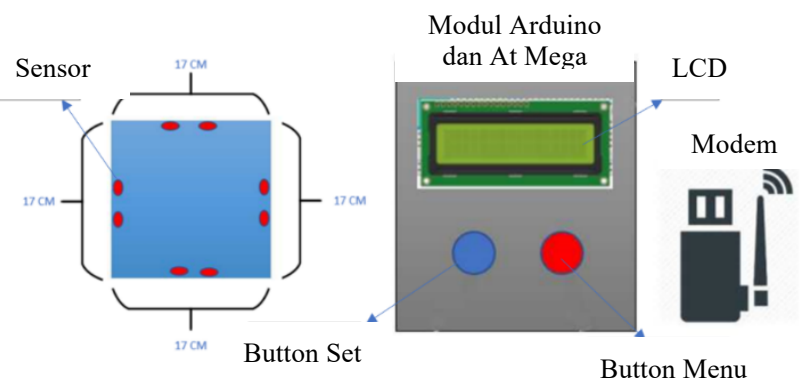

Gambar 5. Sketsa prototype system pendeteksi volume Sampah

Pada pengembangan prototype ini, langkah berikutnya adalah mendesain tata letak komponen. Gambar 5 memperlihatkan tata letak komponen baik sensor, orange pi dan usb wireless modem. Sensor berfungsi untuk mengambil nilai volume sampah pada bak sampah untuk ditampilkan LCD dan LCD berfungsi menampilkan menu pengaturan lokasi sampah. Prototype ini menggunakan modem USB untuk terkoneksi dengan jaringan internet. Orange Pi Berfungsi untuk menjembatani pengiriman data dari arduino ke server. Arduino Nano berfungsi untuk mengelolah data dari sensor.

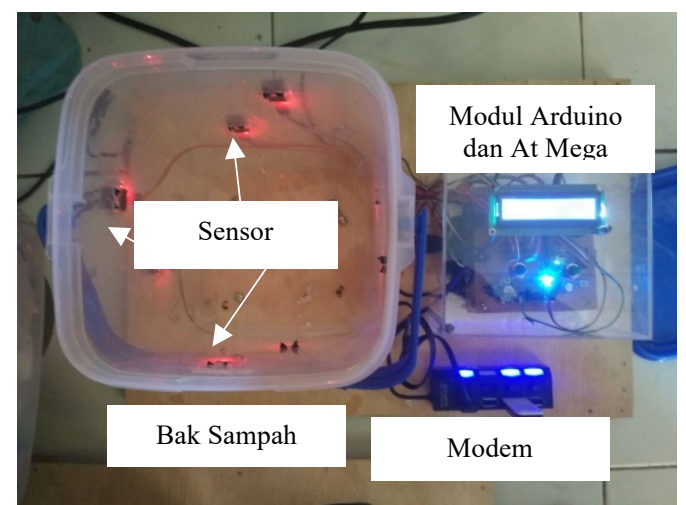

Gambar 6. Prototype Sistem Pendeteksi Volume Sampah Gambar 6 memperlihatkan protoype system pendeteksi volume sampah. Perancangan perangkat ini dibuat semirip mungkin dengan sketsa yang dirancang sebelumnya. Terdapat tiga komponen pokok utama, yang pertama adalah tempat sampah 
yang telah dilengkapi sensor, orange pi dan Arduino uno, dan USB wireless.

Setelah pembuatan alat dan antarmuka selesai, maka dilakukan uji sistem dengan tujuan memperlihatkan hasil yang telah dicapai, dari hasil pengujian didapat data sebagai berikut:

1. LCD Char yang berfungsi untuk menampilkan informasi yang dikehendaki pada sistem

2. Arduino Nano yang berfungsi untuk mengolah data input proses dan output pada sistem

3. Sensor infrared merupakan komponen inputan yang kami manfaatkan sebagai pengukur volume bak sampah

4. Push Button merupakan komponen inputan sama seperti infrared, namun inputan yang diberikan oleh Pust Button berupa nilai dari tombol yang ditekan secara manual

5. USB wireless, komponen ini juga berfungsi untuk menghubungkan perangkat yang disandingkan ke jaringan luar, dalam hal ini perangkat yang dihubungkan ke usb wireless adalah board orange pi

6. Orange Pi, merupakan PC mini yang berfungsi sebagai server yang di dalamnya tesimpan data terolah dari sistem yang dirancang. PC mini ini memiliki sistem operasi armbian (armv7) dengan service yang dipasangkan adalah mysql server, phpmyadmin, apache, dll

7. Perangkat pengguna sebagai media yang digunakan untuk mengakses kedalam sistem informasi yang dipasangkan ke sistem monitoring

8. Terakhir adalah jaringan yang digunakan untuk menghubungkan perangkat sistem adalah jaringan access point / hotspot (lokal)

Pada sistem ini data awal adalah informasi yang diterima dari sistem informasi (gambar 7) berupa data volume sampah. Untuk mendeteksi keadaan volume bak sampah kami memanfaatkan sensor infrared sebagai masukan. Jika sensor mendeteksi sampah perangkat akan meneruskan data yang diterima dari proses perangkat sensor ke server dengan perantaraan jaringan lokal. Data tersebut berupa data sensor dan disimpan kedalam database yang nantinya dapat diakses oleh pengguna menggunakan perangkat komputer atau smartphone dengan mengakses web yang disediakan oleh sistem. Pada tampilan web tersebut kita dapat melihat kondisi volume sampah pada bak dan lokasi tempat sampah.

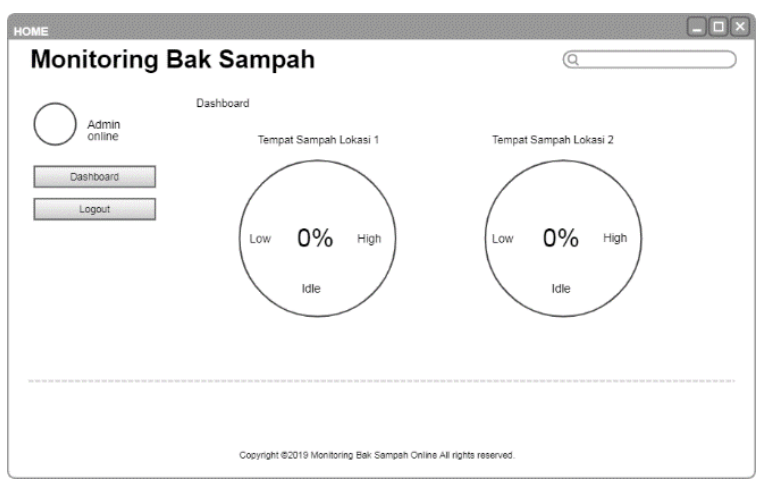

Gambar 7. Rancangan Web Interface Sistem Informasi

\section{HASIL DAN PEMBAHASAN}

\section{Pengujian Koneksi ke Server}

Untuk pengujian koneksi ke server, langkah pertama yang dilakukan adalah Klien dihubungkan ke jaringan lokal menggunakan wifi dan akan didapatkan ip address 192.168.43.64 seperti pada gambar 8 berikut.

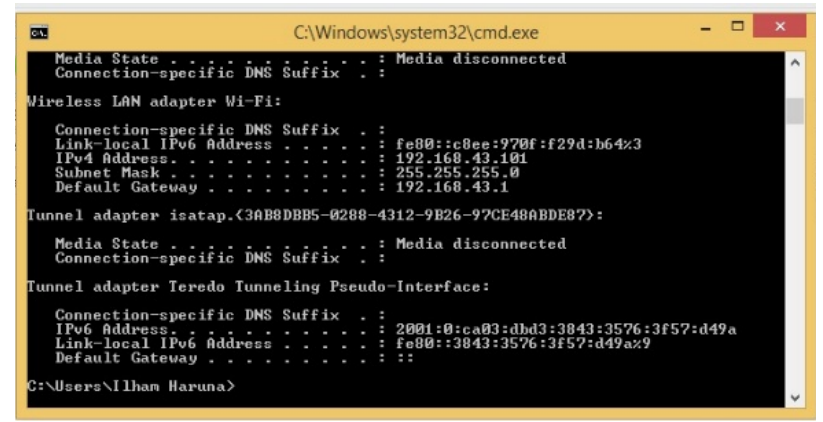

Gambar 8. Ip Address jaringan lokal / server

Kemudian setelah jaringan terhubung maka dilakukan pengujian koneksi ke server dengan melakukan tes ping ke alamat ip server (192.168.43.226). Tes ping ke alamat server dapat dilihat pada gambar 9 berikut :

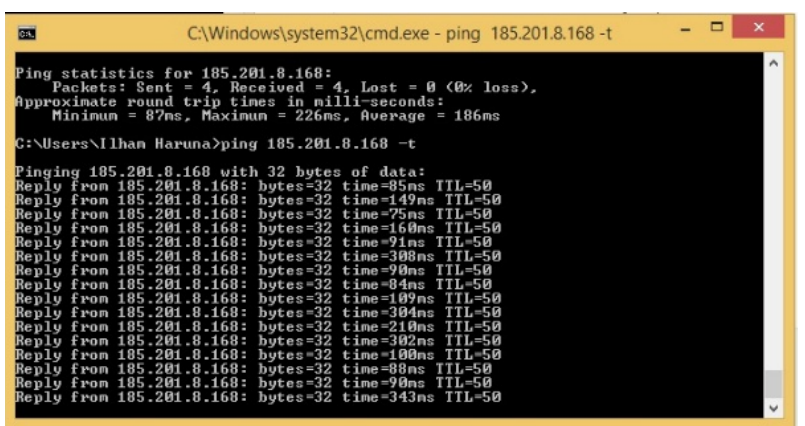

Gambar 9. Tes Ping Ke alamat server (185.201.8.168) Selanjutnya adalah pengujian web server. Pengujian dilakukan menggunakan browser dengan mengakses alamat server. Jika koneksi ke server berhasil dan servis pada server berjalan lancar maka akan tampil seperti gambar 10 berikut :

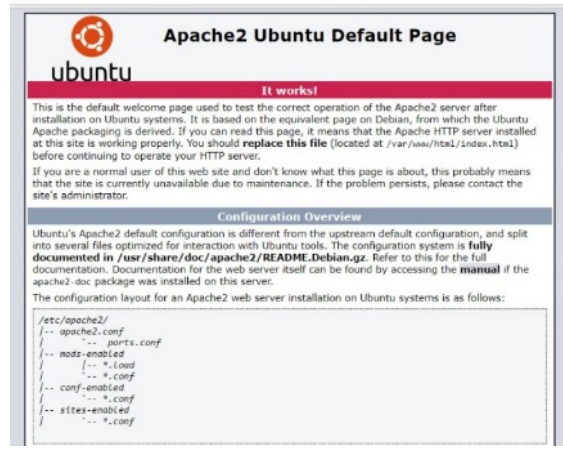

Gambar 10. Servis Web Apache yang berjalan pada server (192.168.43.226)

\section{Pengujian Sistem Informasi Monitoring Sampah}

Pada tahap awal, dilakukan pengujian pada sisi perangkat lunak berupa system monitoring berbasis web yang tersimpan pada server. Untuk alamat web yang telah dibuat pada server adalah http://185.201.8.168:4040 untuk masuk ke dalam sistem 
monitoring. Adapun gambar 11 memperlihatkan tampilan system monitoring berbasis web untuk mengetahui persentasi keterisian bak sampah.

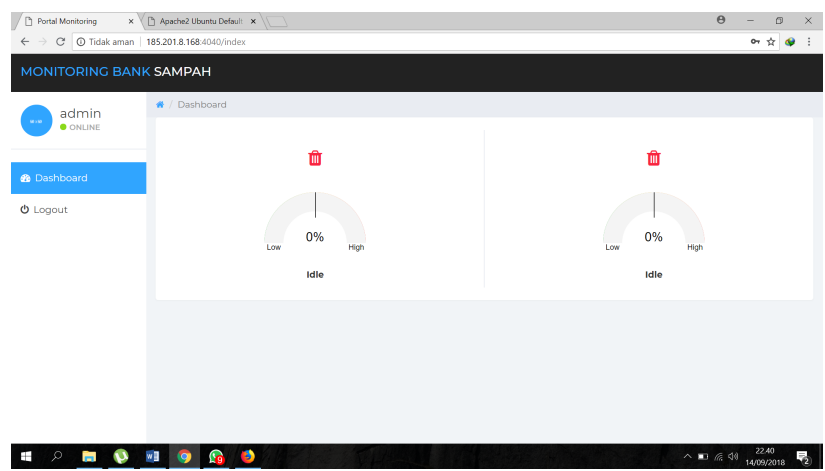

Gambar 11. Dashboard Sistem Monitoring melalui web

Pada halaman web terdapat menu dashboard, serta presentasi volume sampah. Pada menu dashboard kita dapat melihat presentasi volume sampah. tampilan untuk menu dashboard dapat dilihat pada gambar 12 berikut :

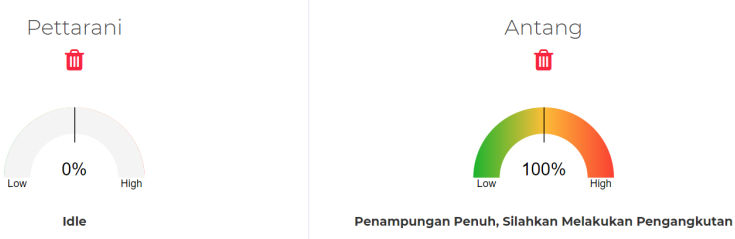

Gambar 12. Halaman Data Monitoring Volume Sampah

\section{Pengujian Monitoring Volume Sampah}

Pada pengujian ini, kami menggunakan dua bak sampah yang berada di lokasi berbeda. Bak sampah diisi sampai penuh sambil dilakukan pengujian monitoring volume sampah. Dari hasil pembacaan sensor pada bak sampah, data dikirim ke server melalui media jaringan wifi, kemudian diolah oleh sistem informasi pada server. Sehingga didapaukan data volume sampah untuk setiap tempat sampah yang berada pada lokasi yang berbeda. Adapun hasil pengujian sistem dilakukan di dua lokasi yaitu di Lokasi 1 dan Lokasi 2, dapat dilihat pada tabel 1:

Tabel 1 Pengujian Monitoring Volume Sampah dengan Tissue

\begin{tabular}{c|c|c}
\hline $\begin{array}{c}\text { Lokasi } \\
\text { Sampah }\end{array}$ & $\begin{array}{c}\text { Volume } \\
\text { Sampah }\end{array}$ & Hasil Uji \\
\hline Lokasi 1 & $100 \%$ & Berhasil \\
\hline Lokasi 2 & $12,5 \%$ & Berhasil \\
\hline
\end{tabular}

Dari tabel 1 pengujian sistem monitoring volume sampah dilakukan dengan cara antara lain :

a. Lokasi 1 volume sampah 100\% pada jam 23:04:00 dan dinyatakan berhasil

b. Lokasi 2 volume sampah 12,5 \% pada jam 23:04:00 dan dinyatakan berhasil.

Data monitoring volume sampah berhasil sesuai lokasi dan volume dilakukan monitoring pada jam 23:04:00, data jadwal disesuaikan sesuai waktu pengujian, dan pengujian dinyatakan berhasil.

\section{Pengujian Kualitas Jaringan}

Untuk menghubungkan dua tempat sampah dengan monitoring server, kami menggunakan jaringan selular beberapa provider. Pengujian ini dilakukan untuk menguji delay pada pengiriman data volume sampah ke server hingga tampil ke system monitoring berbasis web, berikut tabel hasil pengujian kami :

Tabel 2 Lokasi tempat sampah 1

\begin{tabular}{c|c|c|c}
\hline No. & Provider & Delay & Keterangan \\
\hline 1. & Telkomsel & 1 Detik & Berhasil \\
\hline 2. & Axis & 2 Detik & Berhasil \\
\hline 3. & Xl & 1 Detik & Berhasil \\
\hline 4. & Three & 3 Detik & Berhasil \\
\hline
\end{tabular}

Tabel 3 Lokasi tempat sampah 2

\begin{tabular}{c|c|c|c}
\hline No. & Provider & Durasi & Keterangan \\
\hline 1. & Telkomsel & 1 Detik & Berhasil \\
\hline 2. & Axis & 5 Detik & Berhasil \\
\hline 3. & Xl & 4 Detik & Berhasil \\
\hline 4. & Three & 2 Detik & Berhasil \\
\hline
\end{tabular}

Dari table pengujian di atas didapatkan kecepatan transfer data bergantung pada lokasi dan provider yang digunakan untuk mengirim data ke server, hal ini juga dipengaruhi oleh kekuatan sinyal dari Base Transceiver System (BTS) yang diterima oleh modem yang terpasang pada setiap bak sampah.

\section{Pengujian Jarak Sensor}

Pada pengujian jarak sensor yang kami lakukan serta analisa dari seluruh sistem, dengan tujuan untuk mengetahui apakah masingmasing sensor sistem dapat bekerja sesuai dengan yang diharapkan.

\section{Jarak ketika sensor berhadapan dengan sensor}

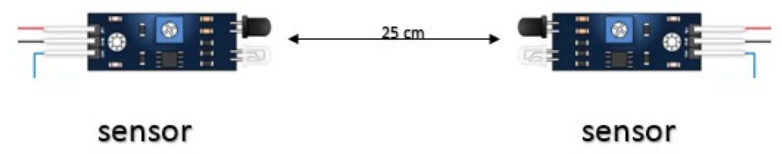

Gambar 13. Pengujian Sensor Pada Saat Saling Berhadapan

Pengukuran dan pengujian ini dilakukan untuk mengetahui ukuran ketika sensor tepat berhadapan dengan sensor, dalam pengujian ini hasil ukuran default yang kami dapatkan maksimal pada jarak $25 \mathrm{~cm}$, jika lebih dari $25 \mathrm{~cm}$ maka sensor tidak bias membaca data.

Jarak ketika sensor tidak saling berhadapan (sensor dengan objek)

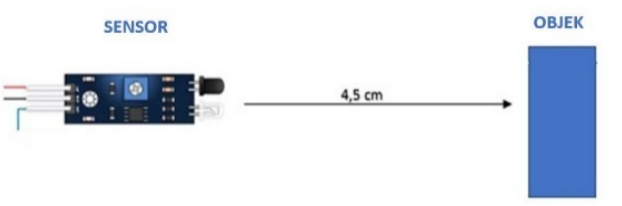

Gambar 14. Pengujian Sensor Saat Berhadapan Dengan Objek

Untuk pengujian jarak sensor berhadapan dengan objek, didapatkan hasil sensor bekerja ketika objek pada jarak 0 hingga maksimal pada jarak 4,5 cm, jika lebih dari 4,5 cm maka sensor 
tidak dapat membaca objek. Sehingga dapat disimpulkan bahwa penempatan sensor pada alat perlu diperhatikan, dimana posisi sensor yang tidak saling berhadapan dapat membaca objek secara keseluruhan dalam bak hingga dinding bak sampah.

\section{Pengujian Pembacaan Sensor}

Pada pengujian ini, dilakukan pemberian nilai default untuk setiap sensor. Dimana pada terdapat 8 (delapan) sensor sehingga masing masing sensor memiliki nilai deault $12.5 \%$. Pada saat satu sensor mendeteksi objek, maka sensor tersebut mengirimkan nilai $12.5 \%$ pada Arduino uno.

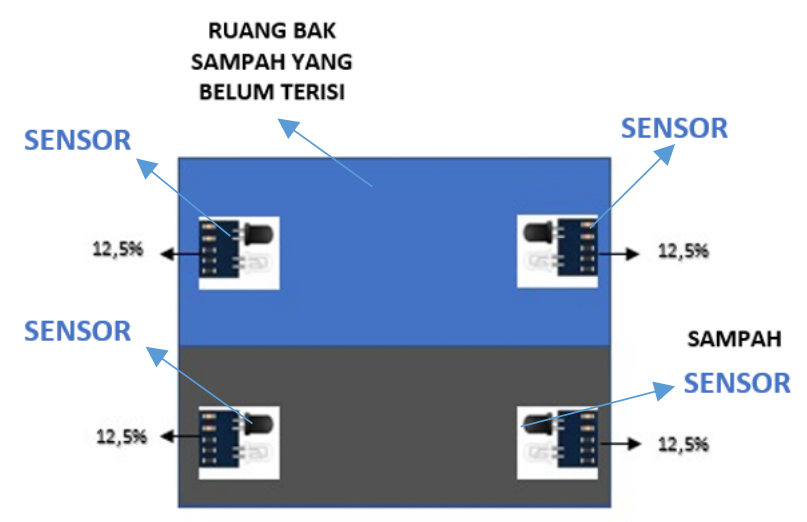

Gambar 15 Pengujian Interval Sensor Pada Objek Sampah Dilihat Dari Tampak Samping

Gambar 15 memperlihatkan pengujian interval kenaikan data pada sensor. Ketika bak sampah tersisi sebanyak 50\%, maka empat sensor akan bernilai masing $12.5 \%$ sehingga total pembacaan yang dikirim ke server adalah $50 \%$. Nilai pembacaan akan berubah ketika sensor pada bagian ruang yang belum terisi mendeteksi objek atau sampah. Sehingga interval dan akurasi pembacaan sensor dengan nilai $12.5 \%$ masih belum ideal. Dibutuhkan tambahan beberapa sensor dan lokasi penempatan sensor untuk menambah kecepatan dan akurasi sensor dalam mendeteksi volume pada bak sampah.

\section{PENUTUP}

Penelitian ini mengembangkan prototype monitoring bak sampah berbasis web untuk menampilkan volume sampah melalui system informasi berbasis web secara real time. Prototype ini diharapkan dapat diimpelementasikan menjadi produk jadi sehingga dapat membantu pihak terkait dalam melakukan proses monitoring sampah pada lokasi tertentu. Apalagi pada beberapa daerah di Indonesia sedang mengembangkan konsep smart city, harapannya prototype ini dapat dijadikan satu implementasi pada smart city untuk monitoring kebersihan lingkungan. Untuk pengembangan selanjutnya, perlunya pengembangan aplikasi monitoring berbasis aplikasi mobile, sehingga dapat dengan mudah melakukan monitoring apalagi untuk sopir pengangkut sampah. Selain itu perlu adanya penambahan jumlah sensor untuk meningkatkan kecepatan dan akurasi deteksi volume sampah dan penggunaan sensor yang dapat mendeteksi jenis sampah basah dan kering.

\section{REFERENCES}

[1] Dayita Andyan Rusti, dkk. Monitoring Pemakaian Energi Listrik Rumah Berbasis Mikrokontroller Secara Wireless. Tugas Akhir School of Electronics and Computer Science, Politeknik Elektronika Negeri Surabaya. 2011.

[2] Engineer, AVR. Arduino Mega 2650, (online) http://atmega32-avr.com/arduino-mega-2560/, diakses tanggal 24 Desember 2016.

[3] Guntoro Helmi, dkk. Pendidikan Teknik Elektro. Rancang Bangun Magnetic Door Lock Menggunakan Keypad Dan Solenoid Berbasis Mikrokontroler Arduino Uno. Jurnal Electrans, Vol.12, No.1 2013.

[4] Kurniadin, Wahyudi. Prototype Sistem Pengunci Pintu Melalui Internet Menggunakan Arduino Uno Berbasis Android. Skirpsi S1 Jurusan Sistem Komputer STMIK Handayani Makassar. 2016.

[5] Manan Mehta. Ark Techno Solutions, ESP 8266: A Breakthrough In Wireless Sensor Networks And Internet Of Things. International Journal of Electronics And Communication Engineering \& Technology (IJECET), Vol.6, Issue.8. 2015.

[6] Rahmat Basir, dkk. Sistem Kendali dan Monitoring Lampu Rumah Menggunakan Mikrokontroller ATMega16 Berbasis Web. Tugas Akhir Program D3 Jurusan Teknik Komputer STMIK Profesional Makassar. 2014.

[7] Vidi Valianto Shaweddy, Pembangunan Sistem Informasi Absensi Dengan Input Fingerprint Dan Barcode Berbasis Web dan Sms Pada Proses Belajar Mengajar. Skripsi Teknik Informatika Universitas Atma Jaya Yogyakarta. 2011.

[8] Winoto, Ardi. Mikrokontroler Atmega8/32/16/8535 dan Pemrogramannya dengan Bahasa $\mathrm{C}$ pada Win AVR. Informatika : Bandung 2008.

[9] Yuniarto, Adhila Rafik. Aplikasi Smart Card Pada Meteran Air Digital Prabayar Berbasis Arduino Mega 2560. Tugas Akhir Teknik Elektro, Fakultas Teknik Universitas Diponegoro. 2014.

[10] Zhao Steven, Orange Pi One. Zhenzhen Xunlong Software Co., Limited. [online] http://www.orangepi.org/orangepione/ (di akses pada tanggal 03-Agustus-2017).

[11] Mohamad Rizal, Analisis Pengelolaan Persampahan Perkotaan (Sudi kasus pada Kelurahan Boya Kecamatan Banawa Kabupaten Donggala). Jurnal SMARTek Vol 9, No 4. 2011.

[12] Bambang Tri Wahjo Utomo, Rancang Bangun Aplikasi Sistem Parkir Mobil Menggunakan Sensor Infra Red di Rumah Sakit Aminah Blitar, Jurnal JITIKA, Volume 6, No. 2, Agustus 2012:1-7

[13] Muchlas, Anton Yudhana, Sigit Wijaya, Tranceiver Infra Merah Termodulasi Untuk Pengendalian Alat-Alat Listrik, TELKOMNIKA Vol. 3, No. 3, Desember 2005 : 177 - 184 